\title{
Characterization of Essential Oils of the Leaves and Fruits of Adenanthera pavonina L. by
} GC/MS

\author{
Mahmoud Mansour ${ }^{\mathrm{a}}$, Eman Al-Sayed ${ }^{\mathrm{b}}$, Mohamed El-Gendy ${ }^{\mathrm{c}}$, Mohamed El-Shazly ${ }^{* \mathrm{~b}, \mathrm{~d}}$, Abdel Nasser \\ Singab ${ }^{* b, e}$ \\ ${ }^{a}$ Department of Pharmacognosy, Faculty of Pharmacy, Egyptian Russian University, Egypt \\ ${ }^{\mathrm{b}}$ Department of Pharmacognosy, Faculty of Pharmacy, Ain Shams University, Cairo 11566, Egypt \\ ${ }^{\mathrm{c}}$ Department of Pharmacognosy, Faculty of Pharmacy, Helwan University, Egypt \\ ${ }^{\mathrm{d} D e p a r t m e n t}$ of Pharmaceutical Biology, Faculty of Pharmacy and Biotechnology, German University in Cairo, \\ Cairo 11835, Egypt \\ ${ }^{\mathrm{e}}$ Centre for Drug Discovery and Development Research, Ain Shams University, Cairo 11566, Egypt
}

\begin{abstract}
The characterization of the hydro distilled essential oils of the leaves and fruits of A. pavonina, growing in Egypt, was analyzed by gas chromatography-mass spectrometry (GC-MS) using Rtx-5MS fused bonded column. The results revealed the identification of 27 compounds in the leaves and fruits oils. The leaves oil consisted mainly of monoterpene hydrocarbons $(68.01 \%)$. The major compounds from the leaves oil were sabinene, accounting for $27.9 \%$ of the oil content followed by D-limonene (14.79\%), 3carene $(8.46 \%)$, caryophyllene $(6.57 \%)$, and $\gamma$-terpinene $(6.16 \%)$. The fruits oil consisted mainly of sesquiterpene hydrocarbons $(62.8 \%)$. The major compounds were $\beta$-element $(39.6 \%)$ followed by sabinene $(11.7 \%)$ and caryophyllene $(11.38 \%)$. These findings will assist in the differentiation between the volatile oils from different parts of $A$. pavonina is a step to establish the first monograph for this plant. This study summarized the chemical profiles of A. pavonina leaves and fruits essential oils growing in Egypt for the first time. The leaves essential oils of $A$. pavonina demonstrated different composition compared with the oils from the fruits.
\end{abstract}

Keywords: Adenanthera pavonina; Fabaceae; GC/MS; Essential oil composition; Sabinene; $\beta$-Elemene.

*Correspondence | Abdel Nasser Singab; Department of Pharmacognosy, Faculty of Pharmacy, Ain Shams University, Cairo 11566, Egypt. Email: dean@pharma.asu.edu.eg

Citation | Mansour M, Al-Sayed E, El-Gendy M, El-Shazly M, Singab A, 2020. Characterization of essential oils of the Leaves and Fruits of Adenanthera pavonina L. by GC/MS. Arch Pharm Sci ASU 4(1): 63-69

DOI: 10.21608 /APS.2020.2001.1027

Print ISSN: 2356-8380. Online ISSN: 2356-8399.

Received 27 February 2020. Accepted 13 April 2020.

Copyright: ${ }^{{ }} 2020$ Singab et al. This is an open-access article licensed under a Creative Commons Attribution 4.0 International License (CC BY 4.0), which permits unrestricted use, distribution, and reproduction in any medium, provided the original author(s) and source are credited.

Published by: Ain Shams University, Faculty of Pharmacy

\section{INTRODUCTION}

Plants containing essential oils were reported to exert various biological activities including antioxidant, antibacterial, and anti-parasitic effects due to the presence of various volatile ingredients with potent effects on various biological receptors. Chemical constituents of essential oils were classified into monoterpenes, sesquiterpenes, isothiocyanates, and phenylpropanoids [1, 2]. The chemical constituents of the volatile oils in different plant organs depend on various factors including the time of collection and plant habitat [3]. 
Fabaceae (Leguminosae) is considered one of the most important families of flowering plants, comprising 727 genera and 19300 species distributed throughout the world [4]. Adenanthera pavonina L. belongs to the Fabaceae. A. pavonina L. is commonly known as redwood and a red-bead tree that is described as a deciduous tree with an erect stem, 18-25 m tall, and $60 \mathrm{~cm}$ in diameter [5].

Leaves are compound, bipinnate with a large swollen pulvinus. The leaflets are oblong to ovate, dull green and turn yellow with age. Fruits are large pods, flattened, dark brown, filled with a sticky brown sweet pulp, dehiscent from the top to bottom by twisting valves (Fig. 1) [6].

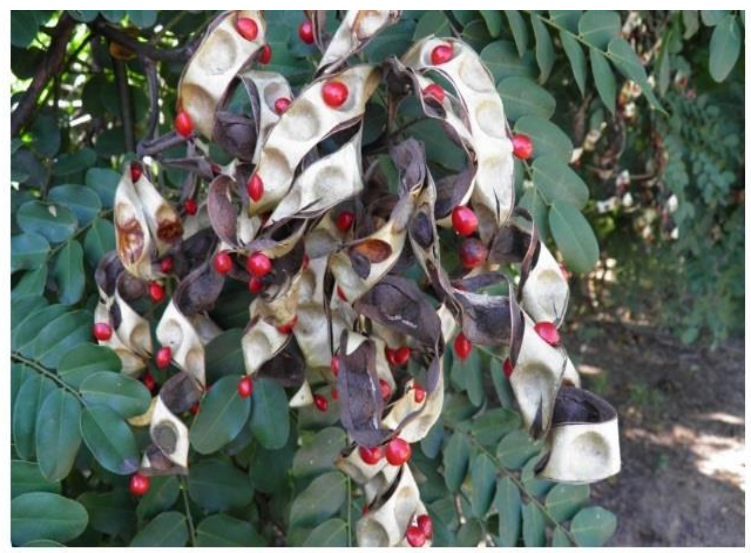

Fig. 1. Adenanthera pavonina leaves and fruits $(\times 0.1)$ http://www.somemagneticislandplants.com.au/.

The leaves of A. pavonina L. showed various biological activities including anti-inflammatory and analgesia [7-9], antihypertensive [10], hepatoprotective [11], hyperlipidemia [12] and antibacterial effects [13]. A. pavonina $\mathrm{L}$. fruits demonstrated anti-inflammatory, antidiabetic [14] and antioxidant [15] activities. Phytoconstituents of A. pavonina L. were classified as flavonoids glycosides, saponins and steroids [16-18]. Despite the widespread use of the plant essential oils in traditional medicine, the chemical components of the oil obtained from the plant grown in Egypt was never studied before. Therefore, the study aimed to characterize the chemical constituents of the essential oils obtained from different organs of A. pavonina (leaves and fruits) growing in Egypt for the first time.

\section{MATERIAL AND METHODS}

\subsection{Plant material}

The leaves and fruits of A. pavonina (Fig. 1) were harvested from El-Orman Botanical Garden, Giza, Egypt. The plant was identified by Mrs. Tereize Labib, the Taxonomy Specialist at El-Orman Botanical Garden. A voucher sample, PHG-P-AP-286 was maintained at the herbarium of the Department of Pharmacognosy, Faculty of Pharmacy, Ain-Shams University.

\subsection{Extraction of the essential oil}

The volatile components of A. pavonina leaves and fruits were isolated by hydrodistillation for $4 \mathrm{~h}$ using a Clevenger-type apparatus at the Pharmacognosy Department, Faculty of Pharmacy, Ain-Shams University to yield $100 \mu \mathrm{L} / 100 \mathrm{~g}$ of the oil. The yielded oil was stored at $-4{ }^{\circ} \mathrm{C}$ in sealed vials.

\subsection{Analysis of essential oil by GC-MS}

A. pavonina oil was analyzed on Shimadzu GCMS-QP2010 (Tokyo, Japan) the operating conditions were as follows: (a) Rtx-5MS fused bonded column $(30 \mathrm{~m} \times 0.25 \mathrm{~mm}$ i.d. $\times 0.25 \mu \mathrm{m}$ film thickness) (Restek, USA), (b) the initial temperature of column was adjusted at $45{ }^{\circ} \mathrm{C}$ for $2 \mathrm{~min}$ (isothermal) and gradually increased to 300 ${ }^{\circ} \mathrm{C}$ at a rate of $5{ }^{\circ} \mathrm{C} / \mathrm{min}$ and remained at $300{ }^{\circ} \mathrm{C}$ for $5 \mathrm{~min}$ (isothermal), (c) the temperature of the injector was $250{ }^{\circ} \mathrm{C}$, (d) the flow rate of the helium carrier gas was $1.41 \mathrm{~mL} / \mathrm{min}$ a split injector, (e) samples (1\% v/v) were injected with split ratio 1:15. Certain conditions adjusted to record mass spectra include Filament emission current (equipment current), $60 \mathrm{~mA}$; ionization voltage, $70 \mathrm{eV}$; ion source, $200{ }^{\circ} \mathrm{C}$. 


\section{RESULTS}

The volatile constituents are listed in Table 1. The identification of the oil components was dependent on the retention index (RI), molecular ion peaks and fragmentation patterns, then these data were compared with the reported data of the reference compounds analyzed under the same conditions in NIST Mass Spectral Library (December 2005) and other reported data [19, 20].

The chromatogram of leaves essential oil revealed the presence of 21 components (Fig. 2) representing $97.9 \%$ of the leaves oil content and 14 components representing $98.7 \%$ of the fruit's oil.

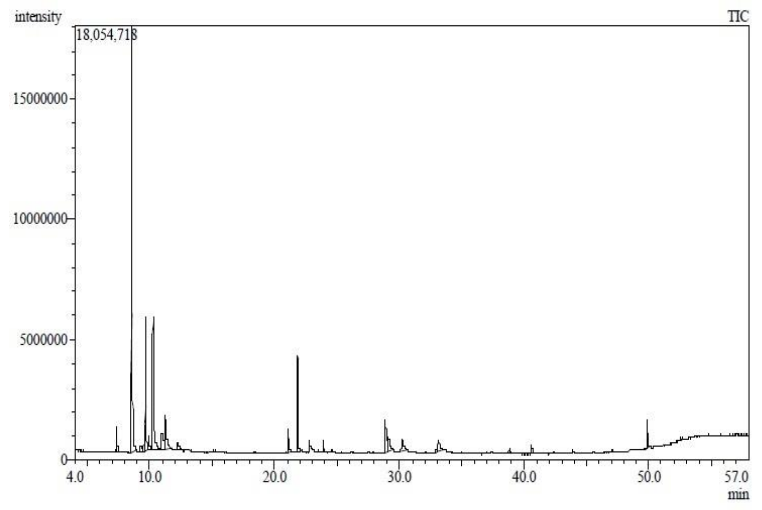

Fig. 2. Chromatogram of Adenanthera pavonina leaves oil

The chemical analysis of the leaves oil showed that the major classes of constituents were monoterpene hydrocarbons $(68.01 \%)$ and sesquiterpene hydrocarbons $(16.8 \%)$. Among the 21 compounds, the major identified components were sabinene $(27.9 \%)$ followed by D-limonene (14.79\%), 3-carene (8.46\%), caryophyllene $(6.57 \%)$ and $\gamma$-terpinene $(6.16 \%)$ (Fig. 3). Regarding the fruit's oil, the results (Fig. 4) showed that the main classes of constituents were sesquiterpene hydrocarbons (62.8\%) and monoterpene hydrocarbons $(20.44 \%)$. The fruits oil consisted of $\beta$-elemene as the main component $(39.6 \%)$ followed by sabinene
(11.7\%), caryophyllene (11.38\%), 3-carene (7.2\%) (Fig. 3).

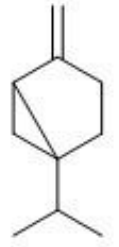

Sabinene<smiles>C=C(C)C1CC=C(C)CC1</smiles>

D-Limonene

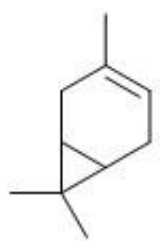

3-Carene

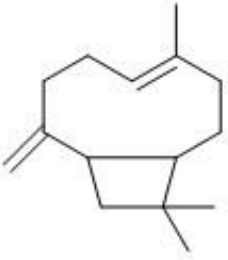

Caryophyllene

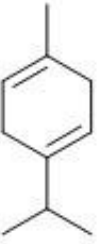

Terpinene

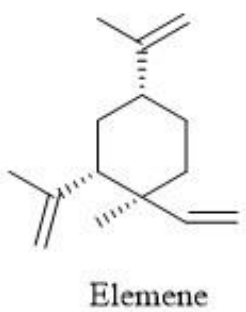

Fig. 3. Structure of sabinene, D-limonene, 3-carene, caryophyllene, $\gamma$-terpinene, $\beta$-elemene

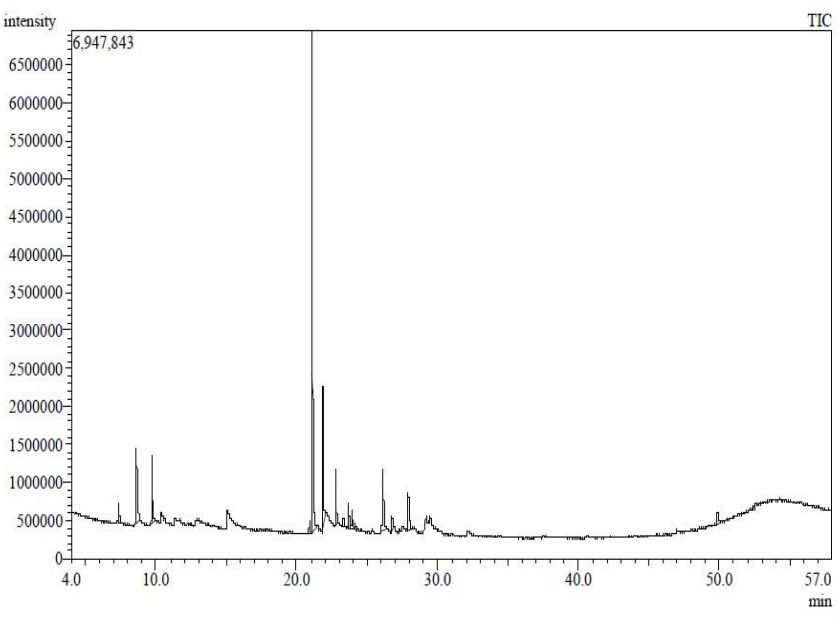

Fig. 4. Chromatogram of Adenanthera pavonina fruits oil 
Table 1: GC-MS analysis of the essential oil

\begin{tabular}{|c|c|c|c|c|c|c|c|}
\hline No. & Component & $\begin{array}{l}\text { RI } \\
\text { observed }\end{array}$ & $\begin{array}{l}\text { RI } \\
\text { literature }\end{array}$ & $\begin{array}{l}\text { \%Area } \\
\text { Leaves }\end{array}$ & $\begin{array}{l}\text { \%Area } \\
\text { Fruits }\end{array}$ & $\begin{array}{l}\text { Molecular } \\
\text { formula }\end{array}$ & Method \\
\hline 1. & $\alpha$-Pinene & 929 & 932 & 1.64 & 1.52 & $\mathrm{C}_{10} \mathrm{H}_{16}$ & $\overline{\mathrm{KI}, \mathrm{MS}}$ \\
\hline 2. & Sabinene & 961 & 969 & 27.93 & 11.7 & $\mathrm{C}_{10} \mathrm{H}_{16}$ & $\mathrm{KI}, \mathrm{MS}$ \\
\hline 3. & $\beta$-Myrcene & 984 & 988 & 1.31 & & $\mathrm{C}_{10} \mathrm{H}_{16}$ & KI, MS \\
\hline & $\alpha$-Phellandrene & 996 & 1002 & 0.71 & & $\mathrm{C}_{10} \mathrm{H}_{16}$ & $\mathrm{KI}, \mathrm{MS}$ \\
\hline & 3-Carene & 1001 & 1008 & 8.46 & 7.2 & $\mathrm{C}_{10} \mathrm{H}_{16}$ & KI, MS \\
\hline & $\alpha$-Terpinene & 1008 & 1017 & 1.79 & & $\mathrm{C}_{10} \mathrm{H}_{16}$ & KI, MS \\
\hline & D-Limonene & 1020 & 1024 & 14.79 & & $\mathrm{C}_{10} \mathrm{H}_{16}$ & $\mathrm{KI}, \mathrm{MS}$ \\
\hline & $\beta$-Ocimene & 1043 & 1044 & 3.29 & & $\mathrm{C}_{10} \mathrm{H}_{16}$ & $\mathrm{KI}, \mathrm{MS}$ \\
\hline & $\gamma$-Terpinene & 1051 & 1054 & 6.16 & & $\mathrm{C}_{10} \mathrm{H}_{16}$ & $\mathrm{KI}, \mathrm{MS}$ \\
\hline & Terpinolene & 1082 & 1086 & 1.67 & & $\mathrm{C}_{10} \mathrm{H}_{16}$ & $\mathrm{KI}, \mathrm{MS}$ \\
\hline 11. & $\beta$-Elemene & 1383 & 1389 & 2.24 & 39.6 & $\mathrm{C}_{15} \mathrm{H}_{24}$ & KI, MS \\
\hline 12. & Caryophyllene & 1411 & 1417 & 6.57 & 11.38 & $\mathrm{C}_{15} \mathrm{H}_{24}$ & KI, MS \\
\hline 13. & Humulene & 1447 & 1452 & 0.48 & 4.43 & $\mathrm{C}_{15} \mathrm{H}_{24}$ & KI, MS \\
\hline 14. & $\beta$-Chamigrene & 1469 & 1476 & & 0.93 & $\mathrm{C}_{15} \mathrm{H}_{24}$ & $\mathrm{KI}, \mathrm{MS}$ \\
\hline 15. & $\beta$-Selinene & 1482 & 1489 & & 2.78 & $\mathrm{C}_{15} \mathrm{H}_{24}$ & KI, MS \\
\hline 16. & Bicyclogermacrene & 1491 & 1509 & 0.85 & 3.05 & $\mathrm{C}_{15} \mathrm{H}_{24}$ & KI, MS \\
\hline & $\alpha$-Bulnesene & 1501 & 1509 & & 0.65 & $\mathrm{C}_{15} \mathrm{H}_{22}$ & $\mathrm{KI}, \mathrm{MS}$ \\
\hline 18. & Caryophyllene oxide & 1578 & 1582 & & 6.82 & $\mathrm{C}_{15} \mathrm{H}_{24} \mathrm{O}$ & $\mathrm{KI}, \mathrm{MS}$ \\
\hline 19. & Humulene epoxide I & 1604 & 1608 & & 1.08 & $\mathrm{C}_{15} \mathrm{H}_{24} \mathrm{O}$ & $\mathrm{KI}, \mathrm{MS}$ \\
\hline 20. & cis-Cadin-4-en-7-ol & 1652 & 1658 & & 6.26 & $\mathrm{C}_{15} \mathrm{H}_{26} \mathrm{O}$ & $\mathrm{KI}, \mathrm{MS}$ \\
\hline & $\beta$-Sinensal & 1693 & 1699 & 6.7 & & $\mathrm{C}_{15} \mathrm{H}_{26}$ & $\mathrm{KI}, \mathrm{MS}$ \\
\hline 22. & 2Z,6E-Farensal & 1705 & 1715 & 3.02 & & $\mathrm{C}_{15} \mathrm{H}_{26} \mathrm{O}$ & $\mathrm{KI}, \mathrm{MS}$ \\
\hline 23. & $\alpha$-Sinensal & 1752 & 1755 & 3.51 & & $\mathrm{C}_{15} \mathrm{H}_{22} \mathrm{O}$ & $\mathrm{KI}, \mathrm{MS}$ \\
\hline & $n$-Nonadecane & 1881 & 1900 & 2.7 & & $\mathrm{C}_{19} \mathrm{H}_{40}$ & $\mathrm{KI}, \mathrm{MS}$ \\
\hline 25 . & Heneicosane & 2180 & 2190 & 0.57 & & $\mathrm{C}_{21} \mathrm{H}_{44}$ & $\mathrm{KI}, \mathrm{MS}$ \\
\hline & Nonacosane & 2854 & 2900 & 2.97 & & $\mathrm{C}_{29} \mathrm{H}_{60}$ & $\mathrm{KI}, \mathrm{MS}$ \\
\hline & Tetratetracontane & 3028 & 3065 & 0.36 & 1.31 & $\mathrm{C}_{44} \mathrm{H}_{90}$ & $\mathrm{KI}, \mathrm{MS}$ \\
\hline Monoterp & ene hydrocarbons & & & 67.75 & 20.44 & & \\
\hline Sesquiterp & pene hydrocarbons & & & 16.84 & 62.8 & & \\
\hline Oxygenat & ed sesquiterpenes & & & 6.7 & 14.1 & & \\
\hline Others & & & & 6.6 & 1.31 & & \\
\hline Total ide & ntified & & & $97.9 \%$ & $98.7 \%$ & & \\
\hline
\end{tabular}

Compounds are listed in order of their elution on a DB-5 GC column; RI observed, Kovats index determined experimentally on a RTX-5 column relative to C8-C28 n-alkanes. RI literature, published Kovats index on a DB-5 column; MS, identification was based on mass spectral data; RI, identification was based on comparison with published Kovats retention indices in NIST Mass Spectral Library (Wiley Registry of Mass Spectral Data, $8^{\text {th }}$ edition) and literature. 


\section{DISCUSSION}

The results of oils characterization demonstrated that there was a significant difference in the chemical profile of the volatile oil obtained from the leaves and fruits of $A$. pavonina. Monoterpene was the main class of oil from the leaves with sabinene as the major identified compound. On the other hand, the results of the fruit's oil showed that sesquiterpene was the major class of oil with $\beta$-elemene as the major identified component.

The results revealed that essential oils obtained from the leaves and fruits of $A$. pavonina can be used as a potential source for different components with various biological activity such as sabinene which exhibited sedative activity [21], potent anti-fungal, antibacterial [22] and anti-inflammatory activity by the inhibition of NO production [23]. DLimonene is used in dietary supplements as it showed antioxidant activity [24] and antibacterial activity [25]. In addition, D-limonene showed antifungal [26] and antibacterial activities [27, 28]. Therefore, it was used in the preservation of food. As the essential oil of A. pavonina leaves contains sabinene and D-limonene as the major constituents, it is recommended to study the antimicrobial activity of the oil. Concerning the components of the fruit's oil, $\beta$-elemene showed considerable antiproliferative effects on many types of cancer cell lines. It has was reported to inhibit brain cancer cell growth and proliferation [29] and showed significant anti-inflammatory activity and antimicrobial activity [30]. Biological investigations on the fruit's oil are recommended to identify the potential applications of the oils.

This study focused on the chemical profiles of A. pavonina leaves and fruits essential oils growing in Egypt for the first time. Identification of the nature of oil constituents is the first step in studying the biologic activities of the oil. Based on the composition of the oils, further biological investigations can lead to the discovery of new leads as antimicrobial agents.

\section{Conflict of Interest}

We declare that we have no conflict of interest.

\section{Declarations}

\section{Ethics approval and consent to participate}

Not applicable

\section{Consent to publish}

Not applicable

\section{Availability of data and materials}

All data generated or analyzed during this study are included in this published article in the main manuscript.

\section{Competing interests}

The authors declare that no competing interests exist

\section{Funding Statement}

No funding source was received.

\section{Authors' contributions}

The manuscript was drafted and written by all authors. All authors have read and approved the final manuscript.

\section{Acknowledgment}

The authors would like to acknowledge all colleagues in the Department of Pharmacognosy, Faculty of Pharmacy, Ain-Shams University for their constructive comments.

\section{List of abbreviations:}

Eos, Essential oils; GC-MS, Gas chromatography and mass spectrometry; RI, Refractive index; NIST, National Institute of Standards and Technology. 


\section{REFERENCES}

1. Wink, M., Modes of action of herbal medicines and plant secondary metabolites. Medicines, 2015. 2(3): p. 251-286 DOI: 10.3390/medicines2030251.

2. Ribeiro-Santos, R., M. Andrade, A. Sanches-Silva, and N.R. de Melo, Essential oils for food application: natural substances with established biological activities. Food and bioprocess technology, 2018. 11(1): p. 43-71 DOI: 10.1007/s11947-017-1948-6.

3. Xiang, H., L. Zhang, Z. Yang, F. Chen, X. Zheng, and $\mathrm{X}$. Liu, Chemical compositions, antioxidative, antimicrobial, anti-inflammatory and antitumor activities of Curcuma aromatica Salisb. essential oils. Industrial Crops and Products, 2017. 108: p. 6-16 https://doi.org/10.1016/j.indcrop.2017.05.058.

4. Lewis, G.P., Legumes of the World. 2005: Royal Botanic Gardens Kew.

5. Mujahid, M., V.A. Ansari, A.K. Sirbaiya, R. Kumar, and A. Usmani, An insight of pharmacognostic and phytopharmacology study of Adenanthera pavonina. Journal of Chemical and Pharmaceutical Research, 2016. 8(2): p. 586-596

6. George, M. and Q. Code, A Review on Antidiarrhoeal, Anti-inflammatory and Antibacterial activity of Adenanthera pavonina leaves. IJPR, 2017. 7(06).

7. Mujahid, M., Phytochemical analysis and evaluation of scavenging activity of methanolic extract of Adenanthera pavonina Linn leaves. Journal of Drug Delivery and Therapeutics, 2015: p. 55-61 DOI: 10.22270/jddt.v5i3.1147.

8. Zeid, A., E. El-Khoury, A. Sleem, and D. Waly, Lipoidal content and anti-inflammatory activity of Adenanthera pavonina L. leaves. Journal of Applied Sciences Research, 2012(January): p. 207214.

9. Ara, A., M. Arifuzzaman, C.K. Ghosh, M.A. Hashem, M.U. Ahmad, S.C. Bachar, et al., Antiinflammatory activity of Adenanthera pavonina L., Fabaceae, in experimental animals. Revista Brasileira de Farmacognosia, 2010. 20(6): p. 929-
932 DOI: 10.1590/s0102-695×2010005000039.

10. Adedapo, A.D., Y.O. Osude, A.A. Adedapo, J.O. Moody, A.S. Adeagbo, O.A. Olajide, et al., Blood pressure-lowering effect of Adenanthera pavonina seed extract on normotensive rats. Records of Natural Products, 2009. 3(2): p. 82

11. Mujahid, M., M.A. Rahman, H.H. Siddiqui, A. Hussain, V.A. Ansari, and M.I. Khan, Phytoconstituents from the Leaves of Adenanthera Pavonina Linn And Erythrina variegata L.(Syn.= Erythrina indica Lam). Current Trends in Biotechnology \& Pharmacy, 2016. 10(1).

12. Krishnaveni, A., S. Selvi, and S. Mohandass, Antidiabetic, hypolipidemic activity of Adenanthera pavonina seeds in alloxan-induced diabetic rats. Journal of Pharmacy Research, 2011. 4(5): p. 1440-1442.

13. Adeyemi, O.A., A.D. Adedapo, A.A. Adedapo, and J.O. Moody, Evaluation of the antimicrobial activity of crude extracts and chromatographic fractions of Adenanthera pavonina Linn (Leguminosae) seeds. African journal of biotechnology, 2015. 14(12): p. $1067-$ 1073 DOI: https://doi.org/10.5897/AJB2015.14437

14. Vieira, I.G.P., F.N.P. Mendes, S.C. da Silva, R.T.T. Paim, B.B. da Silva, S.R. Benjamin, et al., Antidiabetic effects of galactomannans from Adenanthera pavonina L. in streptozotocininduced diabetic mice. Asian Pacific Journal of Tropical Medicine, 2018. 11(2): p. 116 DOI: $10.4103 / 1995-7645.225018$

15. Araujo, N.M.P., G.A. Pereira, H.S. Arruda, L.G. Prado, A.L.T.G. Ruiz, M.N. Eberlin, et al., Enzymatic treatment improves the antioxidant and antiproliferative activities of Adenanthera pavonina L. seeds. Biocatalysis and agricultural biotechnology, 2019. 18: p. 101002 DOI: https://doi.org/10.1016/j.bcab.2019.01.040.

16. Khare, C.P., Indian medicinal plants: an illustrated dictionary. 2008: Springer Science \& Business Media.

17. Su, E., S. Yu, and Y. Pei, Studies on chemical constituents from stems and leaves of Adenanthera pavonine. Zhongguo Zhong yao za zhi= Zhongguo 
Zhong Yao zazhi $=$ China journal of Chinese materia medica, 2007. 32(20): p. 2135-2138

18. Devi, V., P. Biju, D. Devi, T. Cabin, Y. Lija, and A. Abraham, Isolation of robinetin from Adenanthera pavonina and its protective effect on perchlorate induced oxidative damage. J Trop Med Plants, 2007. 7(1): p. 160 DOI.

19. Adams, R.P., Identification of Essential Oil Components By Gas Chromatography/Mass Spectrometry. 4th edition ed. 2007, Illinois, USA: Allured Publishing Corporation.

20. NIST. The National Institute of Standards and Technology (NIST) Chemistry WebBook. NIST Standard Reference Database Number 69. 2017; Available from http://webbook.nist.gov/chemistry/.

21. Dougnon, G. and M. Ito, Sedative effects of the essential oil from the leaves of Lantana camara occurring in the Republic of Benin via inhalation in mice. Journal of Natural Medicines, 2020. 74(1): p. 159-169 doi: 10.1007/s11418-019-013589

22. Chung, N.T., L.T. Huong, and I.A. Ogunwande, Antimicrobial, Larvicidal Activities and Composition of the Leaf Essential Oil of Magnolia coco (Lour.) DC. Rec. Nat. Prod, 2020 http://doi.org/10.25135/rnp.174.20.02.1541

23. Arunkumar, R., S.A. Nair, K.B. Rameshkumar, and A. Subramoniam, The Essential Oil Constituents of Zornia diphylla (L.) Pers, AntiInflammatory and Antimicrobial Activities of the Oil. Records of Natural Products, 2014. 8(4).

24. Bakkali, F., S. Averbeck, D. Averbeck, and M. Idaomar, Biological effects of essential oils-a review. Food and chemical toxicology, 2008. 46(2): $\quad$ p. $446-475$ DOI: https://doi.org/10.1016/j.fct.2007.09.106.

25. Wang, F., H. You, Y. Guo, Y. Wei, P. Xia, Z. Yang, et al., Essential oils from three kinds of fingered citrons and their antibacterial activities. Industrial Crops and Products, 2020. 147: p. 112172

DOI: https://doi.org/10.1016/j.indcrop.2020.112172
26. Chee, H.Y., H. Mm, and M.H. Lee, In vitro antifungal activity of limonene against Trichophyton rubrum. Mycobiology, 2009. 37(3): p. 243-246 DOI: doi: 10.4489/MYCO.2009.37.3.243.

27. Costa, M.D.S., J.E. Rocha, F.F. Campina, A.R. Silva, R.P. Da Cruz, R.L. Pereira, et al., Comparative analysis of the antibacterial and drugmodulatory effect of d-limonene alone and complexed with $\beta$-cyclodextrin. European Journal of Pharmaceutical Sciences, 2019. 128: p. 158-161 DOI: 10.1016/j.ejps.2018.11.036.

28. Jaroenkit, P., N. Matan, and M. Nisoa, In vitro and in vivo activity of citronella oil for the control of spoilage bacteria of semi-dried round scad (Decapterus maruadsi). International Journal of Medicinal and Aromatic Plants, 2011. 1(3): p. 234239.

29. Li, Q.Q., R.X. Lee, H. Liang, and Y. Zhong, Anticancer activity of $\beta$-elemene and its synthetic analogs in human malignant brain tumor cells. Anticancer research, 2013. 33(1): p. 65-76.

30. Sieniawska, E., P. Michel, T. Mroczek, S. Granica, and K. Skalicka-Woźniak, Nigella damascena L. essential oil and its main constituents, damascenine, and $\beta$-elemene modulate the inflammatory response of human neutrophils ex vivo. Food and chemical toxicology, 2019. 125: p. 161-169 DOI: 10.1016/j.fct.2018.12.057. 